\title{
Effect of NPK Rates and Inoculation with Mycorrhizal Fungi on Chamomile (Matricaria chamomilla L.) Plant in Sandy Soils
}

\author{
Abdallah, S. A. S.; M. A. M. Ali and T. O. M. El-Kashef \\ Plant Production Department, Faculty of Environmental Agricultural Sciences, Arish University
}

Received: $17 / 9 / 2018$

\begin{abstract}
This study was carried out during the winter seasons of 2014-15 and 2015-16 at The Experimental Farm of Environmental Agricultural Sciences Faculty, Arish University, North Sinai Governorate, Egypt. The aim of this work was to study the effect of different NPK rates $(0.00,22.4,44.8$ and $67.2 \mathrm{Kg} / \mathrm{fed})$ and different Mycorrhizal fungi concentrations $(0.00,28,56$ and $84 \mathrm{~g} / \mathrm{fed})$ and their interactions on growth and chemical content of dry leaves (nitrogen, phosphorus, potassium), and fresh leaves content of chlorophyll A and B as well as dry flower content of oil of chamomile (Matricaria chamomilla L.) under sandy soil conditions. A Split plot design was used NPK rates were randomly arranged in main plots and the mycorrhizal fungi concentrations were randomly distributed in the sub plots, Drip irrigation was used. Distance between lines was $50 \mathrm{~cm}$ and between plants in the same row was $30 \mathrm{~cm}(28000$ plant per fed). The obtained results showed that the highest values of vegetative growth (plant height, stem diameter, number of branches, fresh and dry weight of herb, root length, and root fresh and dry weight), flower traits (number of folwer/plant, flower fresh and dry weight, and flower diameter), chemical constituents (N, P, K), chlorophyll content (a $\& \mathrm{~b}$ ), and essential oil percentage were achieved when chamomile plants treated with $67.2 \mathrm{~kg} \mathrm{NPK} / \mathrm{fed}$ or $84 \mathrm{~g} /$ fed mycorrhizal fungi. The interaction results indicated that the highest values of all previous traits were recorded with plants fertilized with $67.2 \mathrm{~kg} \mathrm{NPK} /$ fed and inoculated with mycorrhizal fungi at $84 \mathrm{~g} / \mathrm{fed}$.
\end{abstract}

Keywords: Matricaria chamomilla, Mycorrhizal fungi, NPK fertilization

\section{INTRODUCTION}

Chamomile (Matricaria chamomilla L.) has been widely grown in Europe and Iran and it is belongs to family Asteraceae (Farkoosh et al., 2011). In Egypt, the high quality of chamomile flowers and its production during the winter and the early spring months give the crop great opportunities for export to most Europe countries, especially, Germany. Thus, more efforts should be directed toward increasing the productivity of chamomile plant to meet the increment in exports by increasing the cultivated area especially in the promising lands such as North Sinai province.

Application of NPK fertilizer at optimum levels play a key role in growth and development of most physiological processes in the plant as described by Lambers et al. (2000). Nitrogen has an essential role in plants as constituent of proteins, amino acids, nucleic acids, chlorophyll and growth hormones as reported by Russel (1988). The lack of nitrogen used by plants caused depressed of protein synthesis and as a result the plant growth is affected. Phosphorus plays specific roles in the conservation and transfer energy in plants. Also Phosphorus involved in root development processing (Yagodin, 1982). Potassium is known to be linked with carbohydrates metabolism, sugar translocation and cell division and development. Also, potassium increases the resistance of plants versus the drought, pests and diseases (Mengel and Kirkby, 1987).

The influences of NPK on different medicinal plants, however, was reported by Gomaa and Youssef (2007) on fennel, Anwar et al. (2010) on mint, Sabra (2014) on Khella, Hassan et al. (2015) on basil, Khalid and Shedeed (2015) on black-cumin, Milica et al. (2015) on coriander, anise and caraway. With regard to Asteraceae family, Ahmad et al. (2011) showed that application of NPK rates at 15:10:10 $\mathrm{g} \mathrm{m}^{-2}$ caused the maximum values of plant height, flowers length, flowers fresh weight and flowers diameter for marigold plant. The similar results were in family Asteraceae by Massoud et al. (2016), Ahmed et al. (2017) and Ayemi et al. (2017) who found that NPK fertilization improved growth characteristics and essential oil of yarrow, chrysanthemum and gerbera plants, respectively.

The mutual relationship between the plant species and Arbuscular Mycorrhizal (AM) fungi improves the growth of plant especially under the adverse conditions (Farkoosh et al., 2011). This symbiotic association helps host plants to increase the uptake from immobile nutrient elements such as phosphorus, nitrogen, zinc and copper. Also, improve the resistance against the biotic and abiotic stress by induce plant hormones production such as cytokinins and gibberelins (Sharma, 2003). In addition, the symbiosis increases the resistance of AM plants to pathogens such as nematodes (Thangaswamy and Padmanbhan, 2006). Several studies concluded the properties of using the AM fungi in the cultivation of medicinal plants (Al-Amri et al., 2016; Heidari and Deljou, 2014; Yaghoub and Weria, 2013; Zubek et al., 2012). Until now there are scarce studies for using AM fungi on chamomile plants. However, Farkoosh et al. (2011) found that chamomile plants inoculation with AM fungi significantly increased the vegetative growth, flower characteristics and oil yield and content compared with non-inoculated ones.

The aim of this work was to study the effect of NPK fertilization and arbuscular mycorrhizal (AM) fungi and their interaction on vegetative growth, some chemical constituents and essential oil percentage of chamomile (Matricaria chamomilla L.) plant under North Sinai conditions.

\section{MATERIALS AND METHODS}

This study was conducted during 2014/2015 and 2015/2016 seasons in the Experimental Farm of

Volume 7 (1): 29-40 
Environ. Agric. Sci. Fac., Arish University, North Sinai Governorate under sandy soil conditions using drip irrigation system to study the effect of NPK rates combined with arbuscular mycorrhizal fungi concentrations on plant growth, essential oil percentage and some chemical constituents in Matricaria chamomilla L. plant.

The seeds of Matricaria chamomilla L. were sown in the nursery at September $1^{\text {st }}$ in both seasons. Uniform seedlings (about $10 \mathrm{~cm}$ length) were transplanted at November $14^{\text {th }}$. Drip irrigation system was used. The chemical analysis of soil and underground water used for irrigation were carried out using Atomic Absorption Spectrophotometer according to Page (1982) and presented in Table 1.

This experiment included 16 treatments which were the combination of four NPK fertilization rates and four mycorrhizal fungi concentrations. Treatments were arranged in a split plot design with three replicates, where fertilization rates were randomly arranged in the main plots and mycorrhizal fungi concentrations were randomly arranged in the sub plots.

NPK fertilization was applied at rates of 0.00 , 22.4, 44.8 and $67.2 \mathrm{~kg} /$ fed using a compound NPK fertilizer (20:20:20). The amount of chemical fertilizer treatments were divided into eight equal doses, the first dose was applied after two weeks from transplanting, whereas, the other seven doses were applied once every two weeks.

Mycorrhizal fungi vaccine was brought from Agriculture Research Center (ARC), Cairo, Egypt as a powder, mixed with sugar solution (as recommended on package), then added at rates of $0.00,28.0,56.0$ and $84.0 \mathrm{~g} /$ fed before planting in seedlings hills.

The experimental unit area was $10.5 \mathrm{~m}^{2}$ (21m long $\times 0.5 \mathrm{~m}$ wide), every treatment contained three dripper lines. The distance between lines was $50 \mathrm{~cm}$ and between drippers was $30 \mathrm{~cm}$ (between seedlings). Every experimental unit contained 50 plants (about 28000 plant per fed).

Table (1): Mechanical and chemical analysis of soil and underground water

\begin{tabular}{|c|c|c|c|}
\hline \multirow{2}{*}{ Properties } & \multicolumn{2}{|c|}{ Soil } & \multirow{2}{*}{ Water } \\
\hline & $1^{\text {st }}$ season $(2014 / 2015)$ & $2^{\text {nd }}$ season $(2015 / 2016)$ & \\
\hline Mechanical analysis & \multicolumn{3}{|c|}{ Particular size distribution (\%) } \\
\hline Clay & 1.80 & 1.60 & - \\
\hline Silt & 3.10 & 3.40 & - \\
\hline Fine sand & 76.30 & 76.20 & - \\
\hline Coarse sand & 18.80 & 18.80 & - \\
\hline Soil texture & Sandy soil & Sandy soil & - \\
\hline Chemical analysis & \multicolumn{3}{|c|}{ 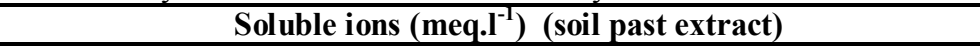 } \\
\hline $\mathrm{Ca}^{++}$ & 3.03 & 2.10 & 18.10 \\
\hline $\mathrm{Mg}^{++}$ & 2.11 & 2.20 & 20.18 \\
\hline $\mathrm{Na}^{+}$ & 1.18 & 4.49 & 17.70 \\
\hline $\mathbf{K}^{+}$ & 0.48 & 0.31 & 0.24 \\
\hline $\mathrm{Cl}^{-}$ & 1.02 & 2.30 & 38.38 \\
\hline $\mathrm{Co}_{3}^{--}$ & - & - & - \\
\hline $\mathrm{Hco}_{3}^{-}$ & 2.00 & 2.40 & 6.23 \\
\hline $\mathrm{So}_{4}^{--}$ & 3.78 & 4.40 & 11.61 \\
\hline $\mathrm{EC}\left(\mathrm{dsm}^{-1}\right)$ & 0.68 & 0.91 & 5.62 \\
\hline pH (1:2.5) & 8.10 & 8.20 & 6.69 \\
\hline Organic carbon $\left(\mathrm{g} . \mathrm{kg}^{-1}\right)$ & 0.93 & 1.22 & - \\
\hline Organic matter $\left({\mathrm{g} . \mathrm{kg}^{-1}}^{\prime}\right)$ & 1.16 & 2.10 & - \\
\hline $\mathrm{Ca} \mathrm{CO}_{3}\left(\mathrm{~g} . \mathrm{kg}^{-1}\right)$ & 3.95 & 3.95 & - \\
\hline
\end{tabular}

Three randomly selected plants from each experimental unit were taken at harvest (started at September and finished at April) and the following data were recorded:

A) Vegetative growth characters; viz, plant height $(\mathrm{cm})$, root length $(\mathrm{cm})$, number of branches /plant, herb fresh and dry weight $(\mathrm{g})$, root fresh and dry weight $(\mathrm{g})$ and stem diameter (mm). B) Floral traits; viz, number of flowers, flower fresh and dry weight $(\mathrm{g})$, and flower diameter $(\mathrm{mm})$. C) Essential oil percentage $(\mathrm{EO} \%)$ in the dry flower heads (it was determined in the second season by water distillation methods according to British Pharmacopoeia (1963). D) Chemical constituents; viz, Chlorophyll a and b (mg/gm) in fresh leaf samples according to Moran (1982), Also, nitrogen, phosphorus and potassium percentages in leaves of the dried herb were determined following the methods of
Bremner and Mulvaney (1982), Olsen and Sommers (1982) and Brown and Lilleland (1946).

All collected data were analyzed with analysis of variance (ANOVA) procedure using the General Linear Models (GLMs) procedures using SAS (SAS, 2004). Differences between means were compared by using Duncan multiple range test at 0.05 level (Duncan, 1955).

\section{RESULTS AND DISCUSSION}

\section{Effect of NPK fertilizer rates:}

\subsection{Vegetative growth characteristics:}

Data in Table (2) indicated that NPK rates affected significantly all vegetative growth traits in both seasons. The highest NPK fertilizer rate $(67.2 \mathrm{~kg} / \mathrm{fed})$ resulted in the highest values of plant height, stem diameter, 
number of branches, herb fresh and dry weight compared with the control and other NPK treatments in both seasons, without significant difference than $(44.8$ $\mathrm{kg}$ /fed) NPK for number of branches in both season. The enhancing effect of NPK on plant growth may be due to that NPK play key role in increasing the phytotosynethetic corresponding to the increases of carboxylation rate and maximum electron transport rate (Mengel and Kirkby, 1987). Also, NPK increased the meristemaic activities and consequently the growth of plants (Lambers et al., 2000). The obtained results in the present study, generally, agreed with many researchers who indicated that the high rates of NPK resulted in higher values of different plants. Khalid and Shedeed (2015) reported that the application of high levels of NPK fertilizer (3:3:3) enhanced the vegetative growth expressed by plant height, leaf number, branch number and herb dry weight in Nigella sativa plant. Also, Massoud et al. (2016) showed that NPK at the rate of 3 $\mathrm{g} /$ pot was the most effective treatment in terms of average shoot length, plant fresh weight and plant dry weight compared with NPK at rates 1 or $2 \mathrm{~g} /$ pot in Achillea millefolium. In addition, Ayemi et al. (2017) indicated that the application of NPK ratio at 17:25.5:34 $\mathrm{g} / \mathrm{m}^{2}$ in Gerbera plant achieved the highest plant height, number of leaves/plant and plant spread compared to the control and other NPK rates. Other findings on chamomile plant indicated that the highest plant height resulted with application of NPK fertilizers at rates of $100: 60: 40 \mathrm{~kg} / \mathrm{ha}$ in compared with non fertilizer plants Upadhyay et al. (2016), the maximum plant height, fresh and dry weight were obtained by using $200 \mathrm{~kg}$ urea/ha Hadi et al. (2015).

Table (2): Effect of NPK rates on vegetative growth of Matricaria chamomilla plant during 2014/2015 and 2015/2016 seasons

\begin{tabular}{|c|c|c|c|c|c|}
\hline NPK(kg/fed) & $\begin{array}{c}\text { Plant } \\
\text { height }(\mathrm{cm})\end{array}$ & $\begin{array}{c}\text { Stem diameter } \\
(\mathrm{mm})\end{array}$ & $\begin{array}{c}\text { No. } \\
\text { branches }\end{array}$ & $\begin{array}{l}\text { Herb fresh } \\
\text { weight (g) }\end{array}$ & $\begin{array}{l}\text { Herb dry } \\
\text { weight (g) }\end{array}$ \\
\hline \multicolumn{6}{|c|}{ First Season } \\
\hline Control & $61.33 \mathrm{c}$ & $6.59 \mathrm{~d}$ & $32.67 \mathrm{~b}$ & $40.82 \mathrm{~d}$ & $14.50 \mathrm{~d}$ \\
\hline 22.4 & $63.91 \mathrm{c}$ & $7.30 \mathrm{c}$ & $34.33 \mathrm{~b}$ & $51.01 \mathrm{c}$ & $17.16 \mathrm{c}$ \\
\hline 44.8 & $70.91 \mathrm{~b}$ & $7.80 \mathrm{~b}$ & $36.67 \mathrm{ab}$ & $62.05 \mathrm{~b}$ & $19.62 \mathrm{~b}$ \\
\hline 67.2 & $77.16 \mathrm{a}$ & $8.21 \mathrm{a}$ & $51.25 \mathrm{a}$ & $69.01 \mathrm{a}$ & $21.27 \mathrm{a}$ \\
\hline \multicolumn{6}{|c|}{ Second Season } \\
\hline Control & $62.66 \mathrm{~d}$ & $6.43 \mathrm{c}$ & $33.67 \mathrm{~b}$ & $47.05 \mathrm{c}$ & $15.91 \mathrm{~d}$ \\
\hline 22.4 & $66.33 \mathrm{c}$ & $6.91 \mathrm{~b}$ & $41.17 \mathrm{~b}$ & $53.19 \mathrm{~b}$ & $17.82 \mathrm{c}$ \\
\hline 44.8 & $74.25 \mathrm{~b}$ & $7.13 \mathrm{~b}$ & $55.25 \mathrm{a}$ & $58.39 \mathrm{~b}$ & $20.58 \mathrm{~b}$ \\
\hline 67.2 & $81.41 \mathrm{a}$ & $8.16 \mathrm{a}$ & $64.58 \mathrm{a}$ & $66.36 \mathrm{a}$ & $22.08 \mathrm{a}$ \\
\hline
\end{tabular}

Values having the same alphabetical letters did not significantly different at 0.05 levels of significant according to Duncan's multiple rang test.

\subsection{Root parameters:}

Data in Table (3) indicated a significant effect for NPK treatments on root length $(\mathrm{cm})$, root fresh and dry weight. Application of $67.2 \mathrm{~kg} /$ fed NPK had the highest value in all traits in both seasons, without significant difference than $(44.8 \mathrm{~kg} / \mathrm{fed}) \mathrm{NPK}$ for root length and root dry weight in the first season. The promotive effect of NPK fertilizer on roots characteristics may be due to the key role of nitrogen in improving cell division and elongation which reflected on root elongation (Yagodin,
1982). The previous results appeared to be in general accordance with those reported by Vembu et al. (2010) who indicated that the application of NPK fertilizer at 30: $40: 40 \mathrm{~kg} / \mathrm{ha}$ resulted in maximum root length, root fresh and dry weight in Catharanthus roseus plants. Also, Omotoso and Shittu (2007) on Okra reported that the highest root length was achieved with using NPK fertilizer at the rate of $150 \mathrm{~kg} / \mathrm{ha}$ compared with unfertilizer plants or $300 \mathrm{~kg} / \mathrm{ha} \mathrm{NPK}$.

Table (3): Effect of NPK rates on root parameters of Matricaria chamomilla plant during 2014/2015 and 2015/2016 seasons

\begin{tabular}{|c|c|c|c|}
\hline $\begin{array}{ll}\text { NPK }(\mathrm{kg} / \mathrm{fed}) & \text { Parameters } \\
\end{array}$ & Root length (cm) & Root fresh weight (g) & Root dry weight (g) \\
\hline \multicolumn{4}{|c|}{ First Season } \\
\hline Control & $11.16 \mathrm{~b}$ & $4.04 \mathrm{~d}$ & $2.05 \mathrm{~b}$ \\
\hline 22.4 & $11.75 \mathrm{~b}$ & $4.61 \mathrm{c}$ & $2.35 \mathrm{~b}$ \\
\hline 44.8 & $12.66 \mathrm{a}$ & $5.54 \mathrm{~b}$ & $2.74 \mathrm{a}$ \\
\hline 67.2 & $12.91 \mathrm{a}$ & $6.12 \mathrm{a}$ & $3.04 \mathrm{a}$ \\
\hline \multicolumn{4}{|c|}{ Second Season } \\
\hline Control & $9.75 \mathrm{c}$ & $3.22 \mathrm{c}$ & $1.65 \mathrm{c}$ \\
\hline 22.4 & $10.91 \mathrm{~b}$ & $4.57 \mathrm{~b}$ & $1.83 \mathrm{bc}$ \\
\hline 44.8 & $11.75 \mathrm{~b}$ & $4.91 \mathrm{~b}$ & $2.19 \mathrm{~b}$ \\
\hline 67.2 & $12.75 \mathrm{a}$ & $5.64 \mathrm{a}$ & $2.94 \mathrm{a}$ \\
\hline
\end{tabular}

Values having the same alphabetical letters did not significantly different at 0.05 levels of significant according to Duncan's multiple rang test. 


\subsection{Flower parameters:}

Data presented in Table (4) indicated that there were significant increases on all studies parameters; i.e., number of flowers/plant, flower fresh weight, flower dry weight and flower diameter due to the application of NPK treatments. Application of 67.2 $\mathrm{kg} /$ fed NPK had the highest value in all traits, without significant difference than applying 44.8 or $22.4 \mathrm{~kg} / \mathrm{fed}$ NPK for flower diameter, while the control treatment had the lowest values in both seasons. The increase in flower parameters according to the application of NPK fertilizer may be due to their stimulatory effect on reserve growth which enhanced reserve food accumulation necessary for flowering and buds initiation. The obtained results seemed to be in general agreement with those reported by Ahmed et al. (2017) who indicated that the maximum plant height, number of flowers, flowers length, flowers weight as well as flowers diameter were recorded with NPK at a rate of 150:75: $135 \mathrm{~kg} / \mathrm{ha}$ in the chrysanthemum plant. Also, Ayemi et al. (2017), they found that application of NPK fertilizer at the rate of $20: 30: 40 \mathrm{~g} / \mathrm{m}^{2}$ had the highest number of flowers/plant and flower diameter in Gerbera plant. Moreover, Massoud et al. (2016) reported that increases of fresh and dry weight of inflorescences (g/plant) of yarrow plant were with application of NPK at a rate of $3 \mathrm{~g} /$ pot.

Table (4): Effect of NPK rates on flower parameters of Matricaria chamomilla plant during 2014/2015 and 2015/2016 seasons

\begin{tabular}{|c|c|c|c|c|}
\hline $\begin{array}{l}P_{\text {NPK(kg/fed })} \text { Parameters } \\
\end{array}$ & No. Flowers/plant & $\begin{array}{l}\text { Flower fresh } \\
\text { weight (g) }\end{array}$ & $\begin{array}{l}\text { Flower dry } \\
\text { weight (g) }\end{array}$ & $\begin{array}{c}\text { Flower diameter } \\
(\mathrm{mm})\end{array}$ \\
\hline \multicolumn{5}{|c|}{ First Season } \\
\hline Control & $39.16 \mathrm{~d}$ & $8.043 \mathrm{~d}$ & $1.31 \mathrm{~d}$ & $7.96 \mathrm{~b}$ \\
\hline 22.4 & $58.83 \mathrm{c}$ & $11.64 \mathrm{c}$ & $1.76 \mathrm{c}$ & $8.18 \mathrm{ab}$ \\
\hline 44.8 & $65.83 \mathrm{~b}$ & $12.50 \mathrm{~b}$ & $2.09 \mathrm{~b}$ & $8.42 \mathrm{ab}$ \\
\hline 67.2 & $73.50 \mathrm{a}$ & $14.13 \mathrm{a}$ & $2.43 \mathrm{a}$ & $8.69 \mathrm{a}$ \\
\hline \multicolumn{5}{|c|}{ Second Season } \\
\hline Control & $51.83 \mathrm{~d}$ & $8.40 \mathrm{~d}$ & $1.47 \mathrm{c}$ & $7.55 \mathrm{~b}$ \\
\hline 22.4 & $56.00 \mathrm{c}$ & $10.93 \mathrm{c}$ & $1.56 \mathrm{c}$ & $7.64 \mathrm{ab}$ \\
\hline 44.8 & $68.50 \mathrm{~b}$ & $12.51 \mathrm{~b}$ & $2.17 \mathrm{~b}$ & $7.74 \mathrm{ab}$ \\
\hline 67.2 & $76.50 \mathrm{a}$ & $14.61 \mathrm{a}$ & $2.49 \mathrm{a}$ & $8.12 \mathrm{a}$ \\
\hline
\end{tabular}

Values having the same alphabetical letters did not significantly different at 0.05 levels of significant according to Duncan's multiple rang test.

\subsection{Chemical constituents and essential oil:}

Data listed in Table (5) indicated a significant effect for NPK treatments on all studied traits; viz., dry leaves content of nitrogen, phosphorus, potassium, and fresh leaves content of chlorophyll ( $a$ and $b$ ) as well as flowers content of essential oil. There were no significant difference between the application of 44.8 $\mathrm{kg} /$ fed and $67.2 \mathrm{~kg} / \mathrm{fed}$ of NPK fertilizer in both seasons on $\mathrm{N}$ content in both seasons, $\mathrm{P}$ content in the second season, and $\mathrm{K}$ content in the first and second season. As regard to chlorophyll content there were no significant differences among the three NPK rates in both seasons. This may suggest that nitrogen, phosphors and potassium play an important role in the physiological processes leading to the synthesis of leaf pigments.

Table (5): Effect of NPK rates on chemical constituents of Matricaria chamomilla leaves during 2014/2015 and $2015 / 2016$ seasons and essential oil percentage in the second season $(2015 / 2016)$

\begin{tabular}{|c|c|c|c|c|c|c|}
\hline $\begin{array}{l}\text { Parameters } \\
\text { NPK(kg/fed) }\end{array}$ & $\begin{array}{l}\mathbf{N} \\
\%\end{array}$ & $\begin{array}{l}\mathbf{P} \\
\%\end{array}$ & $\begin{array}{l}\mathbf{K} \\
\%\end{array}$ & Chl. A & Chl. B & $\begin{array}{c}\mathbf{E O} \\
\%\end{array}$ \\
\hline \multicolumn{7}{|c|}{ First Season } \\
\hline Control & $0.320 \mathrm{c}$ & $0.017 \mathrm{c}$ & $1.88 \mathrm{c}$ & $2.02 \mathrm{~b}$ & $6.83 \mathrm{~b}$ & - \\
\hline 22.4 & $0.369 \mathrm{~b}$ & $0.020 \mathrm{~b}$ & $1.99 \mathrm{bc}$ & $2.19 \mathrm{ab}$ & $6.98 \mathrm{ab}$ & - \\
\hline 44.8 & $0.418 \mathrm{a}$ & $0.021 \mathrm{~b}$ & $2.17 \mathrm{ab}$ & $2.30 \mathrm{ab}$ & $7.08 \mathrm{ab}$ & - \\
\hline 67.2 & $0.433 \mathrm{a}$ & $0.023 \mathrm{a}$ & $2.25 \mathrm{a}$ & $2.42 \mathrm{a}$ & $7.26 \mathrm{a}$ & - \\
\hline \multicolumn{7}{|c|}{ Second Season } \\
\hline Control & $0.405 \mathrm{c}$ & $0.021 \mathrm{c}$ & $2.22 \mathrm{~b}$ & $1.64 \mathrm{~b}$ & $6.74 \mathrm{~b}$ & $0.54 \mathrm{~b}$ \\
\hline 22.4 & $0.425 \mathrm{bc}$ & $0.024 \mathrm{~b}$ & $2.41 \mathrm{ab}$ & $1.89 \mathrm{ab}$ & $7.20 \mathrm{ab}$ & $0.51 \mathrm{~b}$ \\
\hline 44.8 & $0.461 \mathrm{ab}$ & $0.025 \mathrm{ab}$ & $2.48 \mathrm{a}$ & $2.05 \mathrm{a}$ & $7.45 \mathrm{a}$ & $0.47 \mathrm{~b}$ \\
\hline 67.2 & $0.477 \mathrm{a}$ & $0.027 \mathrm{a}$ & $2.62 \mathrm{a}$ & $2.14 \mathrm{a}$ & $7.51 \mathrm{a}$ & $0.64 \mathrm{a}$ \\
\hline
\end{tabular}

Values having the same alphabetical letters did not significantly different at 0.05 levels of significant according to Duncan's multiple rang test.

The obtained results matched well with those of Sarhan et al. (2002) on Taxodium distichum who demonstrated that NPK fertilization at the level of 9 $\mathrm{g} /$ pot $(25: 15: 15)$ had a higher chlorophyll $\mathrm{b}, \mathrm{N}$ and $\mathrm{P}$ in leaf contents. He added that the highest $\mathrm{K}$ content was obtained in plants supplied with 25:15:15 at the rate of 9 g/pot NPK. Also, Ahmad et al. (2011) stated that fertilizing marigold plants with NPK at the rates of 15:20:10, 5:20:10, and 10:20:10 $\mathrm{g} \mathrm{m}^{-2}$ led to increase the content of nitrogen, phosphorus, and potassium in leaves. However, chlorophyll contents were higher in plants fertilized with 15:20:10 $\mathrm{g} \mathrm{m}^{-2}$ NPK. Moreover, Janaki et al. (2016) found that the highest N, P and K contents in wild thyme (Thymus serpyllum) plants were 
produced with NPK at the rates of $\mathrm{N}(150 \mathrm{Kg}$ urea /ha), $\mathrm{P}$ (250 kg phosphorus/ha) and K (150 kg potassium/ha). On the other side, Kozera et al. (2013) reported that the application of NPK at rates of $103.9,209.8,314.7 \mathrm{~kg} / \mathrm{ha}$ significantly decreased the content of phosphorus and potassium in caraway fruits.

Results indicated that the highest essential oil percentage was recorded by application of $67.2 \mathrm{~kg} / \mathrm{fed}$ NPK rate. This result was probably due to that nitrogen fertilization enhanced volatile oil, through playing direct or indirect role in the biosynthesis processes. The obtained results seemed to be in general agreement with those reported by Karami et al. (2008) on Chamomilla recutita who found that the cultivated plants fertilized with $90 \mathrm{~kg} / \mathrm{ha}$ NPK had the maximum oil content, while, in the wild species the highest oil content was in control plants. Also, Massoud et al. (2016) found that the essential oil percentage reached the maximum values as a result to application of NPK at $3 \mathrm{~g} /$ pot. On the other side, Kozera et al. (2013) indicated that the application of NPK at rates of 103.9, 209.8, 314.7 kg/ha significantly decreased essential oil content in caraway fruits.

\section{Effect of mycorrhizal fungi treatments:}

\subsection{Vegetative growth:}

Data presented in Table 6 indicate significant effects for arbuscular mycorrhizal inoculation on all studied traits; viz., plant height, stem diameter, number of branches, herb fresh and dry weight. Application of $84 \mathrm{~g} /$ fed treatment had the highest value in all parameters in both seasons. The positive effects of the AM fungi on vegetative growth may be due to the increases of nutrient and water uptake, and photosynthesis process, production of growth regulating substances. The previous results are in a general accordance with those reported by Asrar and Elhindi (2011) who found that seedlings of marigold had higher highest values of plant height and shoot dry weight under well-watered and water-stressed plants due to the effect of AM fungi than non-mycorrhizal seedlings. Also, Siddur and Garampalli (2016) stated that the inoculation of Centella asiatica plants with three AM fungi encouraged higher number of leaves, shoot length and shoot weight in compared with non-mycorrhizal plants.

Table (6): Effect of mycorrhizal fungi on vegetative growth of Matricaria chamomilla plant during 2014/2015 and 2015/2016 seasons

\begin{tabular}{|c|c|c|c|c|c|}
\hline $\begin{array}{l}\text { Parameters } \\
\text { A.M. }(\text { g/fed }) \\
\end{array}$ & $\begin{array}{l}\text { Plant height } \\
(\mathrm{cm})\end{array}$ & $\begin{array}{c}\text { Stem diameter } \\
(\mathrm{mm})\end{array}$ & No. branches & $\begin{array}{l}\text { Herb fresh } \\
\text { weight (g) }\end{array}$ & $\begin{array}{l}\text { Herb dry } \\
\text { weight(g) }\end{array}$ \\
\hline \multicolumn{6}{|c|}{ First Season } \\
\hline Control & $49.58 \mathrm{~d}$ & $6.13 \mathrm{~d}$ & $24.67 \mathrm{~b}$ & $28.74 d$ & $10.36 \mathrm{~d}$ \\
\hline 28 & $66.75 \mathrm{c}$ & $7.06 \mathrm{c}$ & $39.75 \mathrm{ab}$ & $52.47 \mathrm{c}$ & $15.08 \mathrm{c}$ \\
\hline 56 & $75.08 \mathrm{~b}$ & $7.74 \mathrm{~b}$ & $43.00 \mathrm{a}$ & $60.50 b$ & $20.89 \mathrm{~b}$ \\
\hline 84 & $81.91 \mathrm{a}$ & $8.98 \mathrm{a}$ & $47.50 \mathrm{a}$ & $81.19 \mathrm{a}$ & $26.22 \mathrm{a}$ \\
\hline \multicolumn{6}{|c|}{ Second Season } \\
\hline Control & $49.33 \mathrm{~d}$ & $6.00 \mathrm{~d}$ & $33.42 \mathrm{c}$ & $32.95 \mathrm{~d}$ & $12.49 \mathrm{~d}$ \\
\hline 28 & $67.08 \mathrm{c}$ & $6.87 \mathrm{c}$ & $56.08 \mathrm{ab}$ & $51.73 \mathrm{c}$ & $15.43 \mathrm{c}$ \\
\hline 56 & $75.83 \mathrm{~b}$ & $7.64 \mathrm{~b}$ & $45.17 \mathrm{bc}$ & $63.68 b$ & $22.11 \mathrm{~b}$ \\
\hline 84 & $92.41 \mathrm{a}$ & $8.11 \mathrm{a}$ & $60.00 \mathrm{a}$ & $76.63 \mathrm{a}$ & $26.36 \mathrm{a}$ \\
\hline
\end{tabular}

Values having the same alphabetical letters did not significantly different at 0.05 levels of significant according to

Duncan's multiple rang test.

\subsection{Root parameters:}

Data illustrated in Table (7) indicated significant effect for AM fungi treatment on all studied traits; viz., root length, root fresh and dry weight. Application of 84 $\mathrm{g} /$ fed had the highest value in all traits parameters in both seasons. The increase in all traits of roots in this study may be due to that AM fungi enhanced plant growth. Also, mycorrhizal fungi caused plants' root system development by increasing microbial count, nutrient absorption and soil aggregate stability (Milleret et al., 2009). The previous findings are in the same direction with those reported by Yadav et al. (2013) who observed that the root length and root fresh and dry weight of micropropgated Glycyrrhiza glabra plants significantly improved when inoculated with different AM fungi sources at the beginning of the acclimatization stage. Also, Zou et al. (2014) observed that, inoculation with AM fungi of Poncirus trifoliate significantly increased the root length and root projected area compared with non-mycorrhizal plants. Moreover, Heidari and Deljou (2014) stated that the maximum root dry weight was achieved with the inoculation of $5 \%$ AM fungi in Zinnia plants.

\subsection{Flower parameters:}

Data presented in Table (8) clarify significant effect for AM fungi treatment on all studied traits; viz., number of flowers/plant, flower fresh weight, flower dry weight and flower diameter. Application of $84 \mathrm{~g} / \mathrm{fed}$ treatment had the highest value in all parameters in both seasons, without significant difference than $56 \mathrm{~g} /$ fed for flower diameter in the first season. The increases of flower parameters of plants could be attributed to the increase their absorption of nutrient elements such as phosphorus which is effective in plant blooming (Heidari and Deljou, 2014). These results are in harmony with those of Puschel et al. (2014) who found that AMF inoculation significantly increased number of flowers in Gazani arigens plants. Also, Asrar and Elhindi (2011) and Heidari and Deljou (2014) found that AM fungi inoculation increased the number of flowers in Tagetes erecta and zinnia plants, respectively. 
Table (7): Effect of mycorrhizal fungi on root parameters of Matricaria chamomilla plant during 2014/2015 and 2015/2016 seasons

\begin{tabular}{cccc}
\hline Parameters & Root length (cm) & $\begin{array}{c}\text { Root fresh weight } \\
\text { (g) }\end{array}$ & $\begin{array}{c}\text { Root dry weight } \\
\text { (g) }\end{array}$ \\
\hline Control & \multicolumn{3}{c}{ First Season } \\
\hline $\mathbf{2 8}$ & $9.75 \mathrm{~d}$ & $2.80 \mathrm{~d}$ & $0.92 \mathrm{~d}$ \\
$\mathbf{5 6}$ & $11.91 \mathrm{c}$ & $3.84 \mathrm{c}$ & $1.73 \mathrm{c}$ \\
$\mathbf{8 4}$ & $12.91 \mathrm{~b}$ & $6.20 \mathrm{~b}$ & $3.33 \mathrm{~b}$ \\
\hline & $13.91 \mathrm{a}$ & $7.47 \mathrm{a}$ & $4.19 \mathrm{a}$ \\
\hline Control & & Second Season & $0.85 \mathrm{~d}$ \\
$\mathbf{2 8}$ & $7.58 \mathrm{~d}$ & $2.46 \mathrm{~d}$ & $1.55 \mathrm{c}$ \\
$\mathbf{5 6}$ & $11.08 \mathrm{c}$ & $3.27 \mathrm{c}$ & $2.50 \mathrm{~b}$ \\
$\mathbf{8 4}$ & $12.16 \mathrm{~b}$ & $5.31 \mathrm{~b}$ & $3.73 \mathrm{a}$ \\
\hline
\end{tabular}

Values having the same alphabetical letters did not significantly different at 0.05 levels of significant according to Duncan's multiple rang test

Table (8): Effect of mycorrhizal fungi on flower parameters of Matricaria chamomilla plant during 2014/2015 and 2015/2016 seasons

\begin{tabular}{|c|c|c|c|c|}
\hline $\begin{array}{l}\text { Parameters } \\
\text { A.M. }(\text { g/fed })\end{array}$ & No. Flowers/plant & $\begin{array}{l}\text { Flower fresh } \\
\text { weight (g) }\end{array}$ & $\begin{array}{l}\text { Flower dry } \\
\text { weight(g) }\end{array}$ & $\begin{array}{c}\text { Flower diameter } \\
\text { (mm) }\end{array}$ \\
\hline \multicolumn{5}{|c|}{ First Season } \\
\hline Control & $25.75 d$ & $4.59 \mathrm{~d}$ & $0.55 \mathrm{~d}$ & $6.83 \mathrm{c}$ \\
\hline 28 & $47.75 \mathrm{c}$ & $8.85 \mathrm{c}$ & $1.16 \mathrm{c}$ & $8.19 \mathrm{~b}$ \\
\hline 56 & $67.58 b$ & $13.56 \mathrm{~b}$ & $2.44 \mathrm{~b}$ & $8.84 \mathrm{ab}$ \\
\hline 84 & $96.25 \mathrm{a}$ & $19.30 \mathrm{a}$ & $3.44 \mathrm{a}$ & $9.40 \mathrm{a}$ \\
\hline \multicolumn{5}{|c|}{ Second Season } \\
\hline Control & $20.58 \mathrm{~d}$ & $3.99 \mathrm{~d}$ & $0.80 \mathrm{~d}$ & $5.94 \mathrm{c}$ \\
\hline 28 & $51.66 \mathrm{c}$ & $9.60 \mathrm{c}$ & $1.55 \mathrm{c}$ & $7.91 \mathrm{~b}$ \\
\hline 56 & $84.00 \mathrm{~b}$ & $13.91 \mathrm{~b}$ & $2.09 \mathrm{~b}$ & $8.20 \mathrm{~b}$ \\
\hline 84 & $96.58 \mathrm{a}$ & $18.97 \mathrm{a}$ & $3.24 \mathrm{a}$ & $8.99 \mathrm{a}$ \\
\hline
\end{tabular}

Values having the same alphabetical letters did not significantly different at 0.05 levels of significant according to Duncan's multiple rang test.

2.4 Chemical constituents and essential oil percentage:

Data presented in Table (9) showed significant effects for inoculation with mycorrhizal fungi on all studied traits; viz., nitrogen, phosphorus, potassium, chlorophyll ( $\mathrm{a}$ and $\mathrm{b}$ ) and essential oil percentage. Application of $84 \mathrm{~g} / \mathrm{fed}$ treatment had the highest value of all parameters in both seasons, without significant difference than $56 \mathrm{~g} /$ fed for content of potassium and content of chlorophyll A in the first season. This result may be due to that AM fungi affects pigments and phosphorous content of host plant positively as reported by Asrar and Elhindi (2011). The results also indicated that AM fungi treatment support a higher chlorophyll concentration and these results may be occurred by improving $\mathrm{Mg}^{+2}$ uptake (Giri et al., 2003).

Table (9): Effect of mycorrhizal fungi on chemical constituents of Matricaria chamomilla plant during 2014/2015 and $2015 / 2016$ seasons and essential oil percentage in the second season $(2015 / 2016)$

\begin{tabular}{|c|c|c|c|c|c|c|}
\hline $\begin{array}{l}\text { Parameters } \\
\text { A.M.(g/fed) }\end{array}$ & $\begin{array}{l}\mathbf{N} \\
\%\end{array}$ & $\begin{array}{l}\mathbf{P} \\
\%\end{array}$ & $\begin{array}{l}\mathrm{K} \\
\%\end{array}$ & Chl. A & Chl. B & $\begin{array}{c}\text { EO } \\
\%\end{array}$ \\
\hline \multicolumn{7}{|c|}{ First Season } \\
\hline Control & $0.245 \mathrm{~d}$ & $0.015 \mathrm{~d}$ & $1.33 \mathrm{c}$ & $1.53 \mathrm{c}$ & $5.97 \mathrm{~d}$ & - \\
\hline 28 & $0.282 \mathrm{c}$ & $0.019 \mathrm{c}$ & $2.05 \mathrm{~b}$ & $2.04 \mathrm{~b}$ & $6.90 \mathrm{c}$ & - \\
\hline 56 & $0.419 b$ & $0.021 \mathrm{~b}$ & $2.37 \mathrm{a}$ & $2.64 \mathrm{a}$ & $7.42 \mathrm{~b}$ & - \\
\hline 84 & $0.595 \mathrm{a}$ & $0.026 \mathrm{a}$ & $2.53 \mathrm{a}$ & $2.72 \mathrm{a}$ & $7.86 \mathrm{a}$ & - \\
\hline \multicolumn{7}{|c|}{ Second Season } \\
\hline Control & $0.368 \mathrm{~d}$ & $0.019 \mathrm{~d}$ & $1.79 \mathrm{~d}$ & $1.10 \mathrm{c}$ & $6.13 \mathrm{c}$ & $0.50 \mathrm{bc}$ \\
\hline 28 & $0.417 \mathrm{c}$ & $0.022 \mathrm{c}$ & $2.32 \mathrm{c}$ & $1.94 \mathrm{~b}$ & $7.15 b$ & $0.43 \mathrm{c}$ \\
\hline 56 & $0.456 \mathrm{~b}$ & $0.026 \mathrm{~b}$ & $2.59 \mathrm{~b}$ & $2.19 \mathrm{~b}$ & $7.61 \mathrm{ab}$ & $0.59 \mathrm{ab}$ \\
\hline 84 & $0.527 \mathrm{a}$ & $0.029 \mathrm{a}$ & $3.03 \mathrm{a}$ & $2.48 \mathrm{a}$ & $8.02 \mathrm{a}$ & $0.61 \mathrm{a}$ \\
\hline
\end{tabular}

Values having the same alphabetical letters did not significantly different at 0.05 levels of significant according to Duncan's multiple rang test 
The previous results are in harmony with those of Selvaraj et al. (2009) who observed that inclusion seven different AM fungi species significantly increased $\mathrm{N}, \mathrm{P}$, $\mathrm{K}$ and chlorophyll contents, as compared to noninoculation of patchouli plants. Also, Yadav et al. (2013) indicated that the highest values of the leaves chlorophyll content in plants treated with AM fungi compared with untreated ones of Glycyrrhiza glabra plants. In addition, Karagiannidis et al. (2012) showed that the inoculated Mentha and Origanum plants with AM fungi had the higher $\mathrm{N}, \mathrm{P}, \mathrm{K}$ and contents compared with noninoculated plants.

Concerning essential oil percentage, the results indicated that application of $84 \mathrm{~g} /$ fed treatment had the highest value of essential oil percentage without no significant difference than $56 \mathrm{~g} / \mathrm{fed}$ in the second season. These results are in the same line with those of Selvaraj et al. (2009) who found that the highest essential oil percentage content in the leaves were achieved with the inoculation of AM fungi in Patchouli plants compared with the non- inoculated plants. On the other hand, Badawy (2015) reported that the oil percentage had non significant change due to inoculation mycorrhiza in anise plant compared with no-inoculation plants.

\section{Effect of interaction between NPK rates and mycorrhizal fungi on $M$. chamomilla plant:}

\subsection{Vegetative growth:}

Data presented in Table (10) illustrate a significant effect for interaction between NPK rates and mycorrhizal fungi on all studied traits; viz., plant height, stem diameter, number of branches, herb fresh and dry weight. Application of $67.2 \mathrm{~kg} /$ fed NPK with $84 \mathrm{~g} /$ fed of AM fungi had the tallest plants, stem diameter, herb fresh and dry weight. The highest number of branches were recorded in plants treated with $44.8 \mathrm{~kg} / \mathrm{fed} \mathrm{NPK}$ with 84 $\mathrm{g} /$ fed of AM fungi without significant difference than $67.2 \mathrm{~kg} / \mathrm{fed} \mathrm{NPK}$ with $56 \mathrm{~g} /$ fed of AM fungi in the first season. These results are in harmony with those of Badawy (2015) on anise found that the highest plant height, plant fresh weight and plant dry weight were obtained in plants inoculation with AM fungi and 50\% NPK fertilizer compared with control plants. Also, Chukwuka et al. (2017) proved that inoculation of cassava plants with $30 \mathrm{~g}$ of AM fungi plus $60 \mathrm{~g}$ of NPK significantly gave the highest plant height.

Table (10): Effect of interaction between NPK rates and Mycorrhizal fungi rates on vegetative growth of Matricaria chamomilla plant during 2014/2015 and 2015/2016 seasons

\begin{tabular}{|c|c|c|c|c|c|}
\hline $\begin{array}{r}\text { Parameters } \\
\text { NPK }(\mathrm{kg} / \mathrm{fed}) \text { A.M.(g/fed })\end{array}$ & $\begin{array}{l}\text { Plant height } \\
\text { (cm) }\end{array}$ & $\begin{array}{c}\text { Stem diameter } \\
(\mathbf{m m})\end{array}$ & $\begin{array}{c}\text { No. } \\
\text { branches }\end{array}$ & $\begin{array}{l}\text { Herb fresh } \\
\text { weight }(g)\end{array}$ & $\begin{array}{r}\text { Herb dry } \\
\text { weight }(g)\end{array}$ \\
\hline \multicolumn{6}{|c|}{ First Season } \\
\hline $\begin{array}{c}\text { Control } \\
28 \\
56 \\
84\end{array}$ & $\begin{array}{c}42.33 \mathrm{I} \\
60.00 \mathrm{fg} \\
68.66 \mathrm{e} \\
74.33 \mathrm{~cd}\end{array}$ & $\begin{array}{l}5.36 \mathrm{~h} \\
6.45 \mathrm{fg} \\
7.17 \mathrm{def} \\
7.39 \mathrm{de}\end{array}$ & $\begin{array}{c}29.00 \mathrm{bc} \\
23.33 \mathrm{bc} \\
19.33 \mathrm{c} \\
27.00 \mathrm{bc}\end{array}$ & $\begin{array}{l}22.43 \mathrm{f} \\
38.55 \mathrm{e} \\
41.88 \mathrm{e} \\
60.42 \mathrm{~d}\end{array}$ & $\begin{array}{c}9.18 \mathrm{k} \\
12.59 \mathrm{hi} \\
15.22 \mathrm{fg} \\
21.01 \mathrm{e}\end{array}$ \\
\hline $\begin{array}{c}\text { Control } \\
28 \\
56 \\
84 \\
\end{array}$ & $\begin{array}{c}45.33 \mathrm{I} \\
64.33 \mathrm{ef} \\
69.33 \mathrm{de} \\
76.66 \mathrm{c}\end{array}$ & $\begin{array}{l}5.92 \mathrm{gh} \\
6.83 \mathrm{ef} \\
7.31 \mathrm{de} \\
9.14 \mathrm{bc}\end{array}$ & $\begin{array}{l}30.33 \mathrm{bc} \\
46.67 \mathrm{abc} \\
33.00 \mathrm{bc} \\
49.00 \mathrm{abc}\end{array}$ & $\begin{array}{c}27.21 \mathrm{f} \\
46.16 \mathrm{e} \\
57.94 \mathrm{~d} \\
72.75 \mathrm{bc}\end{array}$ & $\begin{array}{c}10.32 \mathrm{jk} \\
14.08 \mathrm{gh} \\
21.17 \mathrm{de} \\
23.07 \mathrm{~d}\end{array}$ \\
\hline $\begin{array}{c}\text { Control } \\
28 \\
56 \\
84\end{array}$ & $\begin{array}{c}52.33 \mathrm{~h} \\
67.33 \mathrm{e} \\
78.00 \mathrm{c} \\
86.00 \mathrm{ab}\end{array}$ & $\begin{array}{c}6.40 \mathrm{fg} \\
7.47 \mathrm{de} \\
7.86 \mathrm{~d} \\
9.48 \mathrm{ab}\end{array}$ & $\begin{array}{l}36.00 \mathrm{bc} \\
37.33 \mathrm{bc} \\
24.00 \mathrm{bc} \\
74.67 \mathrm{a}\end{array}$ & $\begin{array}{c}27.99 \mathrm{f} \\
61.49 \mathrm{~d} \\
64.97 \mathrm{~cd} \\
93.76 \mathrm{a}\end{array}$ & $\begin{array}{c}10.75 \mathrm{ijk} \\
16.57 \mathrm{f} \\
21.72 \mathrm{de} \\
29.43 \mathrm{~b}\end{array}$ \\
\hline $\begin{array}{c}\text { Control } \\
28 \\
56 \\
84 \\
\end{array}$ & $\begin{array}{l}58.33 \mathrm{~g} \\
75.33 \mathrm{c} \\
84.33 \mathrm{~b} \\
90.66 \mathrm{a}\end{array}$ & $\begin{array}{c}6.83 \mathrm{ef} \\
7.48 \mathrm{de} \\
8.62 \mathrm{c} \\
9.91 \mathrm{a}\end{array}$ & $\begin{array}{c}35.33 \mathrm{bc} \\
30.00 \mathrm{bc} \\
70.33 \mathrm{a} \\
54.33 \mathrm{ab}\end{array}$ & $\begin{array}{l}37.33 \mathrm{e} \\
63.68 \mathrm{~d} \\
77.23 \mathrm{~b} \\
97.83 \mathrm{a}\end{array}$ & $\begin{array}{l}11.17 \mathrm{ij} \\
17.10 \mathrm{f} \\
25.43 \mathrm{c} \\
31.37 \mathrm{a}\end{array}$ \\
\hline \multicolumn{6}{|c|}{ Second Season } \\
\hline $\begin{array}{c}\text { Control } \\
28 \\
56 \\
84 \\
\end{array}$ & $\begin{array}{c}35.33 \mathrm{~h} \\
61.66 \mathrm{e} \\
68.00 \mathrm{~d} \\
85.66 \mathrm{bc}\end{array}$ & $\begin{array}{l}5.07 \mathrm{~h} \\
6.56 \mathrm{ef} \\
6.89 \mathrm{def} \\
7.22 \mathrm{cde}\end{array}$ & $\begin{array}{c}30.67 \mathrm{cde} \\
38.00 \mathrm{~b}-\mathrm{e} \\
21.67 \mathrm{e} \\
43.33 \mathrm{~b}-\mathrm{e}\end{array}$ & $\begin{array}{c}24.29 \mathrm{j} \\
47.23 \mathrm{ghi} \\
52.74 \mathrm{e}-\mathrm{h} \\
63.93 \mathrm{~b}-\mathrm{e}\end{array}$ & $\begin{array}{c}9.21 \mathrm{j} \\
12.26 \mathrm{hi} \\
19.39 \mathrm{e} \\
22.80 \mathrm{~cd}\end{array}$ \\
\hline $\begin{array}{c}\text { Control } \\
28 \\
56 \\
84 \\
\end{array}$ & $\begin{array}{l}47.33 \mathrm{~g} \\
60.66 \mathrm{e} \\
68.00 \mathrm{~d} \\
89.33 \mathrm{~b}\end{array}$ & $\begin{array}{c}5.67 \mathrm{gh} \\
6.68 \mathrm{ef} \\
7.29 \mathrm{cde} \\
7.99 \mathrm{abc}\end{array}$ & $\begin{array}{c}26.67 \mathrm{de} \\
49.33 \mathrm{bcd} \\
50.67 \mathrm{bcd} \\
97.67 \mathrm{a}\end{array}$ & $\begin{array}{c}29.14 \mathrm{j} \\
48.94 \mathrm{fgh} \\
61.23 \mathrm{c}-\mathrm{f} \\
73.45 \mathrm{bc}\end{array}$ & $\begin{array}{c}11.20 \mathrm{ij} \\
16.26 \mathrm{f} \\
21.00 \mathrm{de} \\
22.83 \mathrm{~cd}\end{array}$ \\
\hline $\begin{array}{c}\text { Control } \\
28 \\
56 \\
84\end{array}$ & $\begin{array}{l}54.33 \mathrm{f} \\
62.33 \mathrm{e} \\
83.33 \mathrm{c} \\
97.00 \mathrm{a}\end{array}$ & $\begin{array}{c}5.71 \mathrm{gh} \\
6.34 \mathrm{fg} \\
7.96 \mathrm{abc} \\
8.50 \mathrm{a}\end{array}$ & $\begin{array}{l}33.33 \mathrm{cde} \\
37.00 \mathrm{~b}-\mathrm{e} \\
54.33 \mathrm{bc} \\
56.00 \mathrm{bc}\end{array}$ & $\begin{array}{c}36.05 \mathrm{ij} \\
53.80 \mathrm{e}-\mathrm{h} \\
68.92 \mathrm{bcd} \\
74.79 \mathrm{~b}\end{array}$ & $\begin{array}{c}13.68 \mathrm{gh} \\
16.36 \mathrm{f} \\
23.54 \mathrm{c} \\
28.76 \mathrm{~b}\end{array}$ \\
\hline $\begin{array}{c}\text { Control } \\
28 \\
56 \\
84 \\
\end{array}$ & $\begin{array}{c}60.33 \mathrm{e} \\
83.66 \mathrm{c} \\
83.00 \mathrm{bc} \\
97.66 \mathrm{a}\end{array}$ & $\begin{array}{c}7.58 \mathrm{bcd} \\
7.90 \mathrm{abc} \\
8.44 \mathrm{ab} \\
8.72 \mathrm{a} \\
\end{array}$ & $\begin{array}{c}44.00 \mathrm{~b}-\mathrm{e} \\
40.33 \mathrm{~b}-\mathrm{e} \\
94.33 \mathrm{a} \\
61.33 \mathrm{~b} \\
\end{array}$ & $\begin{array}{c}42.32 \mathrm{hi} \\
56.98 \mathrm{~d}-\mathrm{g} \\
71.83 \mathrm{bc} \\
94.34 \mathrm{a} \\
\end{array}$ & $\begin{array}{c}15.86 \mathrm{fg} \\
16.87 \mathrm{f} \\
24.53 \mathrm{c} \\
31.05 \mathrm{a} \\
\end{array}$ \\
\hline
\end{tabular}

Values having the same alphabetical letters did not significantly different at 0.05 levels of significant according to Duncan's multiple rang test 


\subsection{Root parameters:}

Data presented in Table (11) showed a significant effect for the interaction between NPK rates and mycorrhizal fungi rates on all studied traits; viz., root length, root fresh and dry weight. Regarding root length, application of $67.2 \mathrm{~kg} /$ fed NPK with $84 \mathrm{~g} / \mathrm{fed}$ AM fungi had the highest record with no significant difference than $67.2 \mathrm{~kg} /$ fed NPK with $56 \mathrm{~g} /$ fed AM fungi in both seasons. Regarding root fresh weight, the highest value was with applying $67.2 \mathrm{~kg} /$ fed NPK with $84 \mathrm{~g} / \mathrm{fed}$ AM fungi without significant difference than $44.8 \mathrm{~kg} / \mathrm{fed}$ NPK with $84 \mathrm{~g} /$ fed AM fungi and $67.2 \mathrm{~kg} / \mathrm{fed} \mathrm{NPK}$ rates with $56 \mathrm{~g} /$ fed AM fungi in both seasons. Concerning root dry weight, there was no differences between application of $67.2 \mathrm{~kg} / \mathrm{fed}$ NPK with $84 \mathrm{~g} / \mathrm{fed}$ AM fungi and $67.2 \mathrm{~kg} /$ fed NPK treatments with $56 \mathrm{~g} /$ fed AM fungi in the first season and between $67.2 \mathrm{~kg} / \mathrm{fed}$ NPK with 84 $\mathrm{g} /$ fed AM fungi, $44.8 \mathrm{~kg} /$ fed NPK with $84 \mathrm{~g} /$ fed AM fungi and $67.2 \mathrm{~kg} /$ fed NPK treatments with $56 \mathrm{~g} / \mathrm{fed} \mathrm{AM}$ fungi in the second season.

These results are in agreement with those of AboRekab et al. (2010) who examined the effect of AM fungi and NPK fertilizer at rates of 1.5, 2.0 and $2.5 \mathrm{~g} / \mathrm{l}$ on the date palm plantlets after one year from acclimatization stage. They found that the highest root length and number of roots were in plants treated with $2.5 \mathrm{~g} / 1 \mathrm{NPK}$ with mycorrhiza compared with the control and other treatments.

Table (11): Effect of interaction between NPK rates and mycorrhizal fungi rates on root parameters of Matricaria chamomilla plant during 2014/2015 and 2015/2016 seasons.

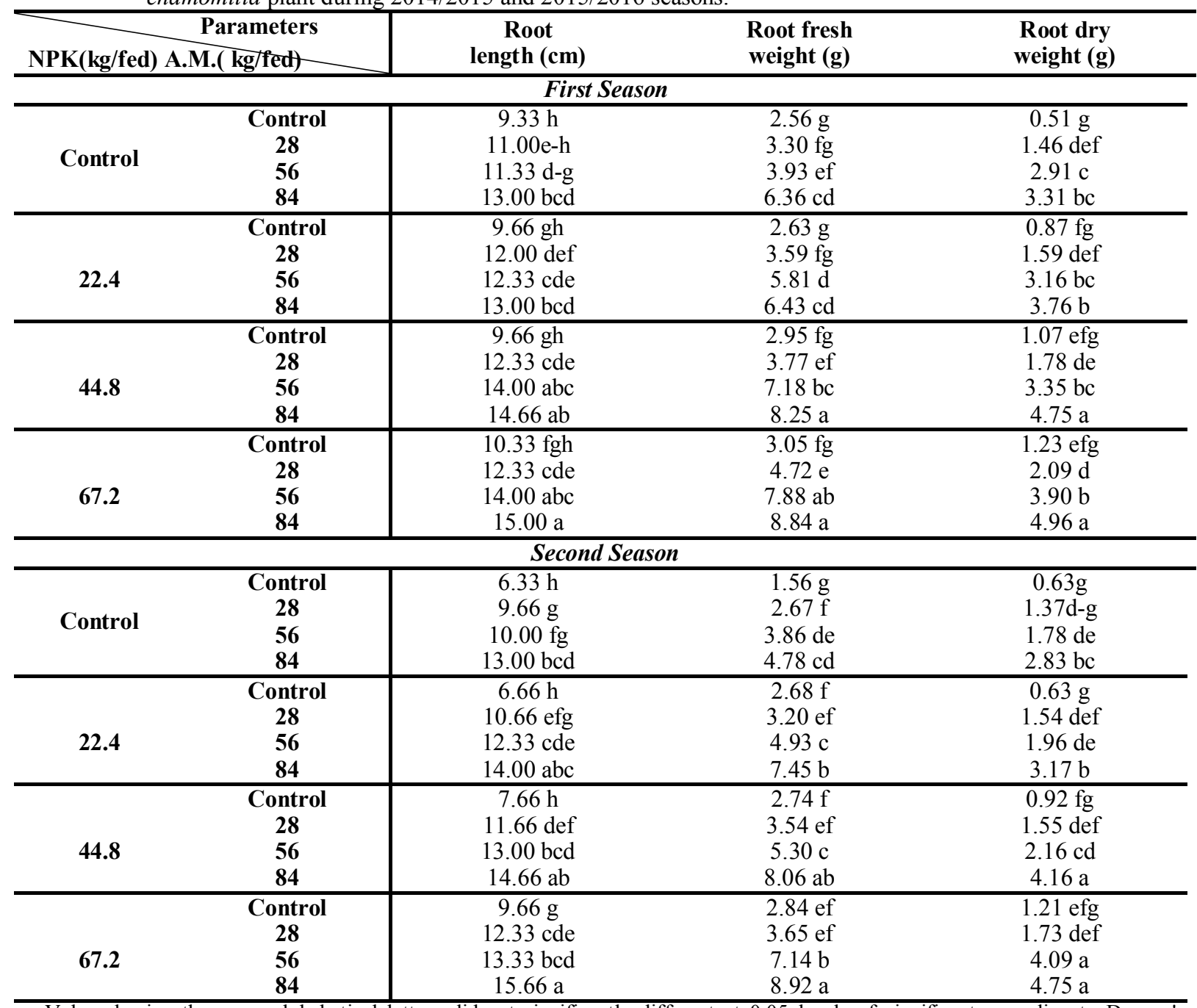

Values having the same alphabetical letters did not significantly different at 0.05 levels of significant according to Duncan's multiple rang test.

\subsection{Flower parameters:}

Data presented in Table (12) showed a significant effect for interaction between NPK and mycorrhizal fungi on all studied traits; viz., flowers number/plant, flower fresh weight, flower dry weight and flower diameter. Application of $67.2 \mathrm{~kg} / \mathrm{fed} \mathrm{NPK}$ with $84 \mathrm{~g} / \mathrm{fed}$ AM fungi had the highest values of all traits without significant difference than $44.8 \mathrm{~kg} / \mathrm{fed}$ NPK with 84 $\mathrm{g} /$ fed AM fungi with for flower diameter in the first season. In this concern Ali and El-Mekawey (2006) indicated that the highest fresh and dry weight of yearly yield of inflorescence (g/plant) resulted in plants fertilizer with NPK fertilization plus farm yard manure of Matricaria chamomilla compared with the control plants. 
Table (12): Effect of interaction rates between NPK fertilization and mycorrhizal fungi on flower parameters of Matricaria chamomilla plant during 2014/2015 and 2015/2016 seasons.

\begin{tabular}{|c|c|c|c|c|c|}
\hline NPK(kg/fed) & $\begin{array}{l}\text { Parameters } \\
\text { A.M. }(\text { g/fed })\end{array}$ & $\begin{array}{c}\text { No. } \\
\text { Flowers/plant }\end{array}$ & $\begin{array}{l}\text { Flower fresh } \\
\text { weight (g) }\end{array}$ & $\begin{array}{l}\text { Flower dry } \\
\text { weight (g) }\end{array}$ & $\begin{array}{l}\text { Flower diameter } \\
(\mathbf{m m})\end{array}$ \\
\hline \multicolumn{6}{|c|}{ First Season } \\
\hline \multirow{4}{*}{ Control } & Control & $19.66 \mathrm{~h}$ & $2.68 \mathrm{I}$ & $0.40 \mathrm{I}$ & $6.72 \mathrm{e}$ \\
\hline & 28 & $40.33 \mathrm{fg}$ & $4.74 \mathrm{~h}$ & 0.73 ghi & 7.95 cde \\
\hline & 56 & $46.66 \mathrm{fg}$ & $10.34 \mathrm{f}$ & $1.89 \mathrm{de}$ & $8.39 \mathrm{bcd}$ \\
\hline & 84 & $50.00 \mathrm{ef}$ & $14.40 \mathrm{~d}$ & $2.24 \mathrm{~cd}$ & $8.77 \mathrm{abc}$ \\
\hline \multirow{4}{*}{22.4} & Control & $22.66 \mathrm{~h}$ & $4.69 \mathrm{~h}$ & $0.48 \mathrm{I}$ & $6.75 \mathrm{e}$ \\
\hline & 28 & $41.66 \mathrm{fg}$ & $7.56 \mathrm{~g}$ & $1.20 \mathrm{fgh}$ & 8.13 cde \\
\hline & 56 & $66.33 \mathrm{~d}$ & $14.04 \mathrm{~d}$ & $1.91 \mathrm{de}$ & $8.77 \mathrm{abc}$ \\
\hline & 84 & $104.66 \mathrm{~b}$ & $20.28 \mathrm{~b}$ & $3.45 \mathrm{~b}$ & $9.09 \mathrm{abc}$ \\
\hline \multirow{4}{*}{44.8} & Control & $23.66 \mathrm{~h}$ & $5.34 \mathrm{~h}$ & $0.63 \mathrm{hi}$ & $6.92 \mathrm{de}$ \\
\hline & 28 & 50.33 ef & $10.78 \mathrm{f}$ & $1.22 \mathrm{fg}$ & $8.16 \mathrm{~b}-\mathrm{e}$ \\
\hline & 56 & $78.33 \mathrm{c}$ & $13.33 \mathrm{de}$ & $2.68 \mathrm{c}$ & $8.92 \mathrm{abc}$ \\
\hline & 84 & $111.0 \mathrm{ab}$ & $20.55 \mathrm{ab}$ & $3.85 \mathrm{ab}$ & $9.70 \mathrm{ab}$ \\
\hline \multirow{4}{*}{67.2} & Control & $37.00 \mathrm{~g}$ & $5.68 \mathrm{~h}$ & 0.69 ghi & $6.92 \mathrm{de}$ \\
\hline & 28 & $58.66 \mathrm{de}$ & $12.34 \mathrm{e}$ & $1.52 \mathrm{ef}$ & $8.52 \mathrm{abc}$ \\
\hline & 56 & $79.00 \mathrm{c}$ & $16.54 \mathrm{c}$ & $3.29 \mathrm{~b}$ & $9.29 \mathrm{abc}$ \\
\hline & 84 & $119.3 \mathrm{a}$ & $21.97 \mathrm{a}$ & $4.23 \mathrm{a}$ & $10.03 \mathrm{a}$ \\
\hline & \multicolumn{5}{|c|}{ Second Season } \\
\hline \multirow{4}{*}{ Control } & Control & $9.33 \mathrm{j}$ & $3.04 \mathrm{I}$ & $0.43 \mathrm{f}$ & $5.71 \mathrm{c}$ \\
\hline & 28 & $39.66 \mathrm{~h}$ & $8.15 \mathrm{~g}$ & $1.31 \mathrm{de}$ & $7.83 \mathrm{~b}$ \\
\hline & 56 & $76.00 \mathrm{ef}$ & $9.85 \mathrm{efg}$ & $1.45 \mathrm{de}$ & $7.97 \mathrm{~b}$ \\
\hline & 84 & $82.33 \mathrm{de}$ & $12.57 \mathrm{~d}$ & $2.68 \mathrm{bc}$ & $8.68 \mathrm{ab}$ \\
\hline \multirow{4}{*}{22.4} & Control & $12.33 \mathrm{j}$ & $3.18 \mathrm{I}$ & $0.49 \mathrm{f}$ & $5.87 \mathrm{c}$ \\
\hline & 28 & $39.66 \mathrm{~h}$ & $9.38 \mathrm{fg}$ & $1.44 \mathrm{de}$ & $7.84 \mathrm{~b}$ \\
\hline & 56 & $76.00 \mathrm{ef}$ & $11.58 \mathrm{de}$ & $1.49 \mathrm{de}$ & $8.12 \mathrm{~b}$ \\
\hline & 84 & $96.00 \mathrm{bc}$ & $19.60 \mathrm{~b}$ & $2.81 \mathrm{bc}$ & $8.73 \mathrm{ab}$ \\
\hline \multirow{4}{*}{44.8} & Control & 24.66 I & $4.57 \mathrm{hi}$ & $1.05 \mathrm{e}$ & $6.04 \mathrm{c}$ \\
\hline & 28 & $58.00 \mathrm{~g}$ & $9.85 \mathrm{efg}$ & $1.60 \mathrm{de}$ & $7.87 \mathrm{~b}$ \\
\hline & 56 & $88.33 \mathrm{~cd}$ & $14.52 \mathrm{c}$ & $2.44 \mathrm{c}$ & $8.18 \mathrm{~b}$ \\
\hline & 84 & $103.0 \mathrm{ab}$ & $21.11 \mathrm{ab}$ & $3.59 \mathrm{a}$ & $8.87 \mathrm{ab}$ \\
\hline \multirow{4}{*}{67.2} & Control & $36.00 \mathrm{~h}$ & $5.17 \mathrm{~h}$ & $1.21 \mathrm{e}$ & $6.15 \mathrm{c}$ \\
\hline & 28 & $69.33 \mathrm{f}$ & $11.01 \mathrm{def}$ & $1.85 \mathrm{~d}$ & $8.11 \mathrm{~b}$ \\
\hline & 56 & $95.66 \mathrm{bc}$ & $19.69 \mathrm{~b}$ & $2.99 \mathrm{~b}$ & $8.53 \mathrm{~b}$ \\
\hline & 84 & $105.0 \mathrm{a}$ & $22.58 \mathrm{a}$ & $3.90 \mathrm{a}$ & $9.70 \mathrm{a}$ \\
\hline
\end{tabular}

Values having the same alphabetical letters did not significantly different at 0.05 levels of significant according to Duncan's multiple rang test.

\subsection{Chemical constituents and essential oil percentage:}

Data presented in Table (13) showed a significant effect for interaction between NPK treatment and mycorrhizal fungi on all studied traits; viz., nitrogen, phosphorus potassium, chlorophyll and essential oil percentage. The highest contents of N, P, K and chlorophyll a \& b were recorded with application of $67.2 \mathrm{~kg} / \mathrm{fed}$ NPK and inoculation with $84 \mathrm{~g} / \mathrm{fed}$ AM fungi without significant difference than $67.2 \mathrm{~kg} / \mathrm{fed}$ NPK and $56 \mathrm{~g} /$ fed AM fungi for potassium percentage and chlorophyll a \& b in both seasons. These results are in corroborate with Badawy (2015) who reported that plants treated with mycorrhiza plus 50 or $75 \%$ of NPK fertilizer had the highest $\mathrm{N}, \mathrm{P}, \mathrm{K}$ leaf content of anise plants. Also, Chukwuka et al. (2017) found that the highest chlorophyll contents were obtained with AM fungi plus NPK fertilizer at rates of $30 \mathrm{~g}$ compared with the control plants in cassava plants.
It was noticed that, the highest value of essential oil percentage was achieved by $67.2 \mathrm{~kg} /$ fed NPK plus 84 $\mathrm{g} /$ fed AM fungi. This result is in agreement with those of Badawy (2015) who concluded that the highest oil yields/fed were resulted in plants treated with mycorrhiza plus 50 or $75 \%$ of NPK fertilizer in anise plant. Also, Ali and El-Mekawey (2006) observed that the highest volatile oil percentage and volatile oil yield (1/fed) were in $M$. chamomilla plants were recorded with fertilized NPK fertilization plus farm yard manure.

\section{CONCLUSION}

In conclusion, addition of chamomile plants with NPK fertilizer at the rate of $67.2 \mathrm{~kg} /$ fed plus inoculation of AM fungi at a rate of $84 \mathrm{~g} / \mathrm{fed}$ gave the highest vegetative growth, flower characteristic, number of roots, root lengt and essential oil percentage under sandy soil of El-arish region. 
Table (13): Effect of interaction between NPK rates and mycorrhizal fungi on chemical constituents of Matricaria chamomilla plant during 2014/2015 and 2015/2016 seasons and essential oil percentage in the second season $(2015 / 2016)$

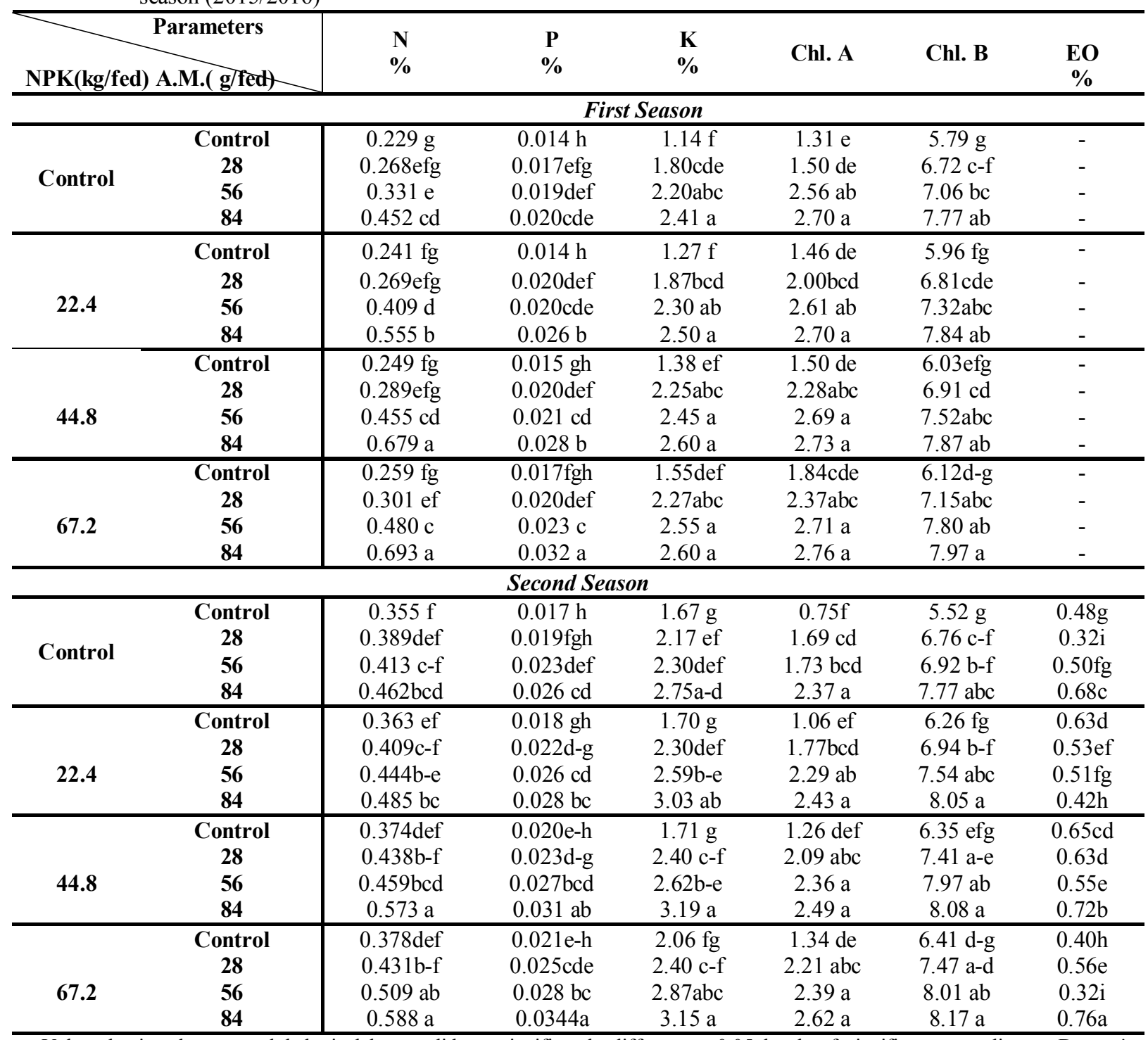

Values having the same alphabetical letters did not significantly different at 0.05 levels of significant according to Duncan's multiple rang test.

\section{REFERENCES}

Abo-Rekab, Z. A., R. S. S. Darwesh and N. Hasan (2010). Effect of arbuscular mycorrhizal fungi, NPK complete fertilizers on growth and concentration nutrients of acclimatized date plam plantlets. Mesopotomia Journal of Agriculture, 38:1-11.

Ahmad, I., M. Asif, A. Amjad and S. Ahmad (2011). Fertilization enhances growth, yield, and xanthophyll contents of marigold. Turkey Journal of Agriculture, 35: 641-648.

Ahmed, R., M. J. Hussain, S. Ahmed, M. R. Karim and M.A. Siddiky (2017). Effect of N, P and K fertilizer on the flower yield of Chrysanthemum. The Agriculturists, 15(1): 5867.
Al-Amri, S. M., K. M. Elhindi and A. F. Sharaf El-Din (2016). Effects of arbuscular mycorrhizal fungus Glomus mosseae and phosphorus application on plant growth rate, essential oil content and composition of coriander (Coriander sativum L.). Progress in Nutrition, 18(4): 443-454.

Ali, M. A. M and M. A. El-Mekawy (2006). Effect of some fertilizer types and drip irrigation rates on productivity of Matricaria chamomilla L. plant under El-arish region conditions. Agriculture Research Journal, suez Canal University, 6: 108-120.

Anwar, M., S. Chand and D. Patra (2010). Effect of graded levels of NPK on fresh herbage yield, oil yield and oil composition of six cultivars of 
menthol mint (Mentha arvensis L.). Indian J. Nat Prod. Resour., 1: 74-79.

Asrar, A. A. and K. M. Elhindi (2011). Alleviation of drought stress of marigold (Tagetes erecta) plants by using Arbuscular mycorrhizal fungi. Saudi Journal of Biological Sciences, 18: 93-98.

Ayemi, T. J., D. Singh and U. Fatmi (2017). Effect of NPK on plant growth, flower quality and yield of gerbera (Gerbera jamesonii L. cv. ruby red) under naturally ventilated polyhouse conditions. Int.J.Curr. Microbiol. App. Sci., 6(8): 1049-1056.

Badawy, M. Y. M. (2015).Studying the possibility of cultivating Pimpinella anisum plant under Sinai conditions by using chemical fertilization and mycorrhiza. Egyptian J. Desert Res., 65 (2): 215-232.

Bremner, J. M. and C. S. Mulvaney (1982). Nitrogen total. P. 595-624. In A. L. Page (ed.), Methods of Soil Analysis. Agron. No. 9, Part 2: Chemical and microbiological properties, $2^{\text {nd }}$ ed., Am. Soc. Agron., Madison, WI, USA.

British Pharmacopoeia (1963). Determination of Volatile Oil in Drugs. The Pharmaceutical Press, London.

Brown, J. D. and O. Lilleland (1946). Rapid determination of potassium and sodium in plant material and soil extracts by flame photometry. Proc. Amer. Soc. Hort. Sci., 48: 341-364.

Chukwuka, K. S., R. U. Okechukwu, B. O. Umukoro and M. C. Obiakara (2017). Arbuscular mycorrhiza fungi, NPK (15-15-15) and cow dung interaction in sustainable cassava production and food security. Adv. Plants Agric. Res., 7(4): 328 $\square 335$.

Duncan, B. D. (1955). Multipe ranges and multiple F test. Biometrics, 11: 1-42.

Farkoosh, S. S., M. R. Ardakani, F. Rejali, M. T. Darzi and A. H. Faregh (2011). Effect of mycorrhizal symbiosis and Bacillus coagolance on qualitative and quantitative traits of Matricaria chamomilla under different levels of phosphorus. Middle-East J. Sci. Res., 8(1): 1-9.

Giri, B., R. Kapoor and K. G. Mukerji (2003). Influence of arbuscular mycorrhizal fungi and salinity on growth, biomass and mineral nutrition of Acacia auriculiformis. Biol. and Fertility of Soils, 38: 170-175.

Gomaa, A. O. and A. S. M. Youssef (2007). Biofertilizers as a partial alternative to chemical NPK fertilization and its influence on the productively of fennel plants (Foeniculum vulgare, Miller).The third Conf. of Sustain. Agric. Develop. Fac. of Agric., Fayoum Univ., 327-352.

Hadi, M. R. H. S., M. A. Fallah and M. T. Darzi (2015). Influence of nitrogen fertilizer and vermicompost application on flower yield and essential oil of chamomile (Matricaria chamomile L.). J. Chemical Health Risks, 5(3): 235-244.
Hassan, M. R. A., A. H. M. El-Naggar, E. H. Shaban and M. E. A. Mohamed (2015). Effect of NPK and bio-fertilizers rates on the vegetative growth and oil yield of Ocimum basillicum L. Plants. Alexandria Science Exchange Journal, 36: 5872.

Heidari, Z. and M. J. N. Deljou (2014). Improvement of morpho-physiological traits and antioxidant capacity of zinnia (Zinnia elegance 'Dreamland Red') by arbuscular mycorrhizal fungi (Glomus mosseae) inoculation. Int. J. Adv. Biol. Biom. Res. 2(10): 2627-2631.

Janaki P., R. S. Adhikari and J. S. Negi (2016). Effect of Nitrogen, Phosphorus and Potassium on Growth and Green Herb Yield of Thymus serphyllum. Int.J.Curr. Microbiol.App.Sci. 5(1): 406-410.

Karagiannidis, N., T. Thomidis, E. Panou-Filotheou, C. Karagiannidou (2012). Response of three mint and two oregano species to Glomusetunicatum inoculation. Austr. J. Crop Sci., 6: 164-169.

Karami, A., M. Khush-Khui and F. Sefidkon (2008). Effects of nitrogen, phosphorus and potassium on yield, essential oil content and composition of cultivated and wild population of Chamomilla recutita L. Rauschert, Journal of Medicinal and Aromatic Plant Sciences, 30: 1-4.

Khalid, K. A. and M. R. Shedeed (2015). Effect of NPK and foliar nutrition on growth, yield and chemical constituents in Nigella sativa L. J. Mater. Environ. Sci., 6(6): 1709-1714.

Kozera, W., E. Majcherczak and B. Barczak (2013). Effect of varied NPK fertilisation on the yield size, content of essential oil and mineral composition of caraway fruit (Carum carvi L.). J. Elem., 2: 255-267.

Lambers, H., F. S. Chapin and T. L. Pons (2000). Plant Physiological Ecology. Springer-Verleg, New York. Inc.

Massoud, H. Y., H. H. Abdel-Kader, F. R. Ibrahim and A. M. Ibrahi (2016). Effect of Mineral Fertilizer and Compost on Vegetative Growth and Essential Oil Content of Yarrow (Achillea millefolium L.) Plant. J. Plant Production, Mansoura Univ., 7(6): 559-565.

Mengel, K. and A. Kirkby (1987). Principles of Plant Nutrition $4^{\text {th }}$ Ed. International Potash. Institute. Bern. Switzerland.

Milica, G. A., K. D. Zeljke, I. O. Snezana, D. K. Dusan and V. O. Mico (2015). Effect of organic and mineral fertilizers on essential oil content in caraway, anise and coriander fruits. Acta Sci. Pol., Hortorum Cultus, 14(1): 95-103.

Milleret, R., R. C. Le Bayon and J. M. Gobat (2009). Root mycorrhiza and earthworm interactions: their effects on soil structuring processes, plant and soil nutrient concentration and plant biomass. Plant and Soil., 316(1): 1-12.

Moran, R. (1982). Formula for determination of chlorophyllous pigments extracted with N,NDimethylformamide. Plant Physiol., 69:13761381 . 
Olsen, S. R. and L. E. Sommers (1982). Phosphorus. In: Page, A.L., Miller, R.H., Keeney, D.R. (Eds.). Methods of Soil Analyses, Part 2, chemical and microbiological properties, $2^{\text {nd }}$ ed. American Society of Agronomy, Madison, WI, USA, pp. 403-430.

Omotoso, S. O. and O. S. Shittu (2007). Effect of NPK fertilizer rates method of application in growth and yield of Okra (Abelmoschus esculensus L. moench) at Ado-Ekiti, South Western Nigeria. International Journal of Agricultural Research, 2: 614-619.

Page, A. L. (1982). Methods of Soil Analysis. Part2: chemical and microbiological properties. $\left(2^{\text {nd }}\right.$ ed.) Amer. Soc. Agron., In Soil Sci. Amer. Inc, Madison, Wisconsin, USA.

Puschel, D., J. Rydlova and M. Vosatka (2014). Can mycorrhizal inoculation stimulate the growth and flowering of peat-grown ornamental plants under standard or reduced watering? Applied Soil Ecology, 80: 93-99.

Russel, E. W. (1988). "Soil Condition and Plant Growth" $11^{\text {th }}$ ed Language Soc. Longman, London.

Sabra, M. M. (2014). Physiological studies on khella (Ammi visnaga) plant. M.Sc. Thesis, Fac. Agric., Fayoum University.

Sarhan, A., T. Abou-Dahab, A. M. Abdel-Dayem and A. R. Rabie (2002). NPK fertilization of Taxodium distichum seedlings.proc. $2^{\text {nd }}$. Inter Conf. Hort Sci., 10-12 Sept. Kafr El-Sheikh, Tanta Univ., Egypt: 1342-1358.

SAS (2004). SAS/STAT User's Guide. SAS Institute Inc., Cary, N.C.

Selvaraj, T., M. Nisha and S. Rajeshkumar (2009). Effect of indigenous arbuscular mycorrhizal fungi on some growth parameters and phytochemical constituents of Pogostemon patchouli Pellet. MaejoInt J. Sci. Tech., 3: 222-234.

Sharma, A. K. (2003). Biofertilizers for Sustainable Agriculture. Agrobios, India, p.: 407.
Siddur, S. H. and R. H. Garampalli (2016). Efficacy of three arbuscular mycorrhizal fungi on growth of Centella asiatica L. (Urban). Asian J. Plant Sci. Res., 6(3):11-16.

Thangaswamy, S. and C. H. Padmanbhan (2006). Arbuscular mycorrhizae: Adiverse personality. Journal of Central European Agriculture, 7: 349-58.

Upadhyay, R. K., V. R. Singh and S. K. Tewari (2016). New agro-technology to increase productivity of chamomile (Matricaria chamomilla L.). Industrial Crops and Products, 89: 10-13.

Vembu, G., R. Singaravel and S. KAmaraj (2010). Effect of NPK levels on the growth and yield of Catharanthus roseus in coastal sandy soil. Asian J. Soil Sci., 5(1): 97-99.

Yadav, K., A. Aggarwal and N. Singh (2013). Arbuscular mycorrhizal fungi induced acclimatization and growth enhancement of Glycyrrhiza glabra L.: A Potential Medicinal Plant. Agric Res., 2(1): 43-47.

Yaghoub, R. and W. Weria (2013). Arbuscular mycorrhizal fungi associated with some aromatic and medicinal plants. Bull Environ, Pharmacol. Life Sci., 2: 129-138.

Yagodin, B. A. (1982). Agricultural Chemistry, Part 1. Mir Publishers. Moscow, USSR. Minneapolis, Minnesota, USA.

Zou,Y., Q. S. WU, Y. Li and Y. M. Huang (2014). Effects of arbuscular mycorrhizal fungi on root system morphology and sucrose and glucose contents of Poncirus trifoliate. Chinese Journal of Applied Ecology, 25(4): 1125-1129.

Zubek, S., A. M. Stefanowicz, J. Blaszkowski, M. Niklinska and K. Seidler-lozykowska (2012). Arbuscular mycorrhizal fungi and soil microbial communities under contrasting fertilization of three medicinal plants. Appl. Soil Ecol., 59: 106-115.
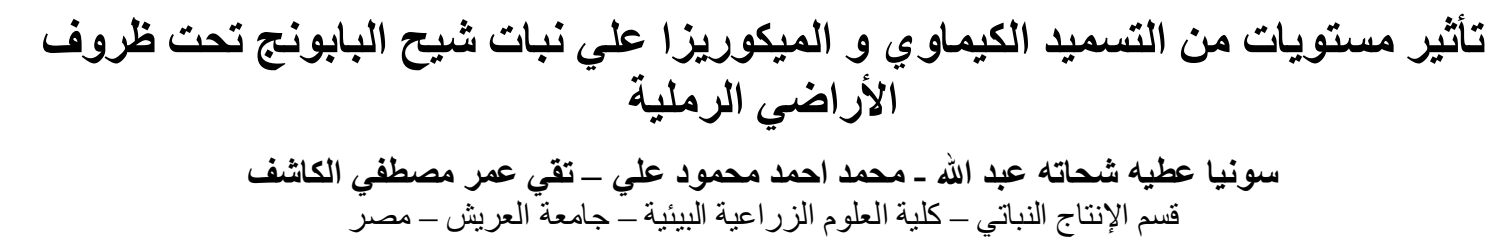

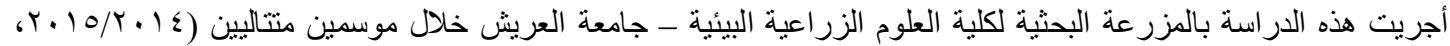

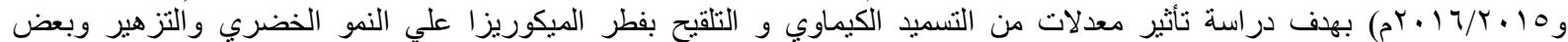

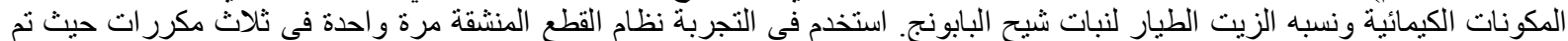

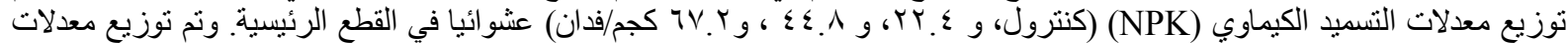

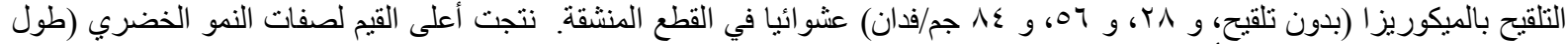

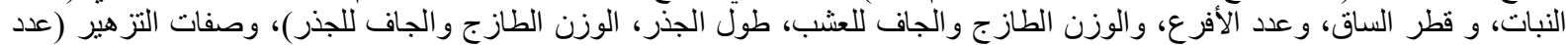

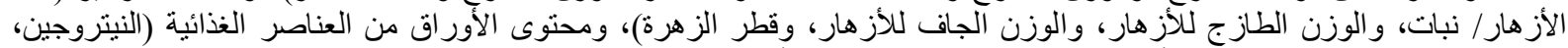

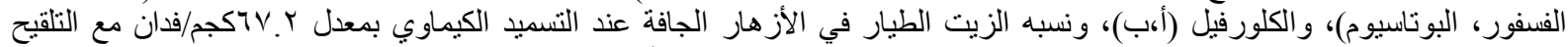

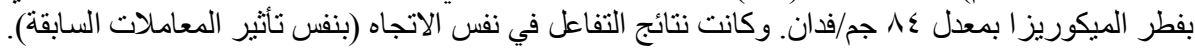

